\title{
Correction to: Targeting the epidermal growth factor receptor in non-small cell lung cancer cells: the effect of combining RNA interference with tyrosine kinase inhibitors or cetuximab
}

Gang Chen ${ }^{1,2}$, Peter Kronenberger ${ }^{1,3}$, Erik Teugels ${ }^{1}$, ljeoma Adaku Umelo ${ }^{1}$ and Jacques De Grève ${ }^{1 *}$

Correction to: BMC Med (2012) 10:28

https://doi.org/10.1186/1741-7015-10-28

Following publication of the original article [1], the authors reported that there was an error in Fig. 9, which contained a misplaced picture. The authors confirm that all of the published results and conclusions of the paper remain unchanged, as well as the figure legends. The authors apologize for any confusion caused. The corrected Fig. 9 is shown as follows:

\footnotetext{
Author details

'Laboratory of Medical and Molecular Oncology and Department of Medical Oncology, Universitair Ziekenhuis Brussel, Vrije Universiteit Brussel, Laarbeeklaan 101, 1090 Brussels, Belgium. ' ${ }^{2}$ eppartment of Pathology, First Affiliated Hospital, Guangxi Medical University, Shuangyong Road 6, 530021 Nanning, Guangxi, People's Republic of China. ${ }^{3}$ Department of Gezondheidszorg, Erasmushogeschool Brussel, Laboratory for Biotechnology, Laarbeeklaan 125, 1090 Brussels, Belgium.
}

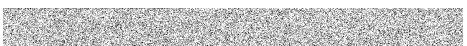

\section{Reference}

1. Chen G, Kronenberger P, Teugels E, Umelo IA, De Grève J. Targeting the epidermal growth factor receptor in non-small cell lung cancer cells: the effect of combining RNA interference with tyrosine kinase inhibitors or cetuximab. BMC Med. 2012;10:28. https://doi.org/10.1186/1741-7015-10-28 PubMed PMID: 22436374; PubMed Central PMCID: PMC3334713.

The original article can be found online at https://doi.org/10.1186/1741-7015$10-28$

* Correspondence: Jacques.Degreve@uzbrussel.be

${ }^{1}$ Laboratory of Medical and Molecular Oncology and Department of Medical Oncology, Universitair Ziekenhuis Brussel, Vrije Universiteit Brussel, Laarbeeklaan 101, 1090 Brussels, Belgium

Full list of author information is available at the end of the article

(c) The Author(s). 2020 Open Access This article is distributed under the terms of the Creative Commons Attribution 4.0 International License (http://creativecommons.org/licenses/by/4.0/), which permits unrestricted use, distribution, and reproduction in any medium, provided you give appropriate credit to the original author(s) and the source, provide a link to the Creative Commons license, and indicate if changes were made. The Creative Commons Public Domain Dedication waiver (http://creativecommons.org/publicdomain/zero/1.0/) applies to the data made available in this article, unless otherwise stated. 

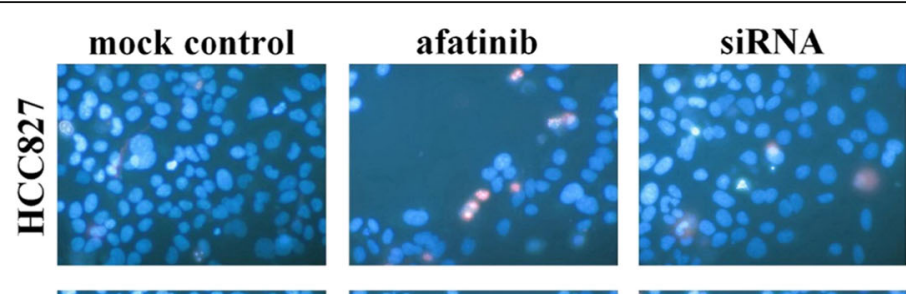

afatinib+ siRNA
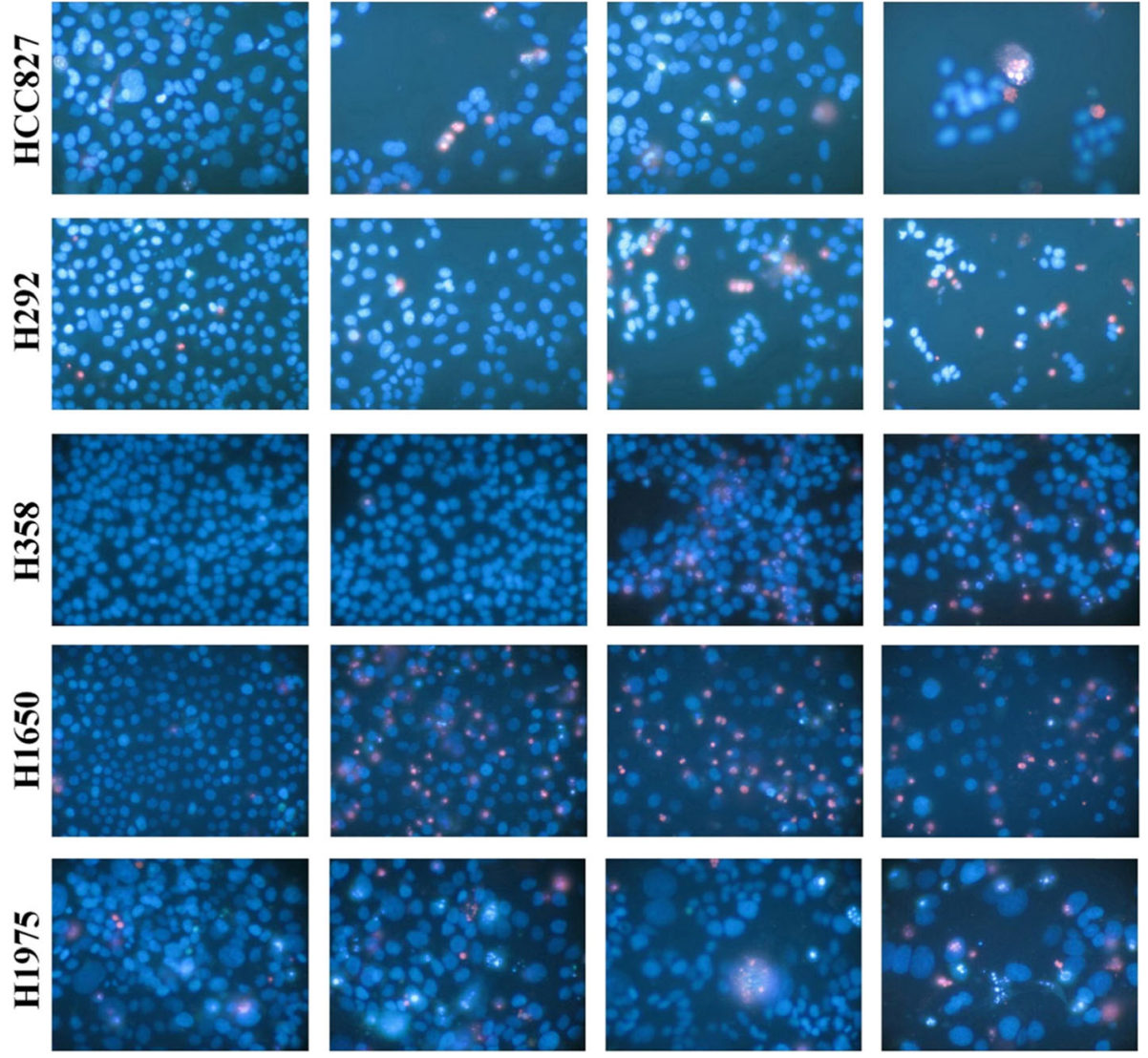

Fig. 9 Effect of combination of EGFR siRNA and afatinib with Hoechst 33342 and PI double fluorescent staining. Effect of the combination of an EGFR siRNA and afatinib detected by Hoechst 33342 and PI double fluorescent staining. The concentrations were afatinib: $0.01 \mathrm{nM}$ (assayed $72 \mathrm{~h}$ post treatment) and EGFR siRNA: $200 \mathrm{nM}$ (assayed $48 \mathrm{~h}$ post transfection). Similar results were found with other concentrations of afatinib, and other drugs in all the five cell lines (data not shown). 